\title{
INTRAVITREAL BEVACIZUMAB FOR NEOVASCULAR GLAUCOMA
}

\author{
Biljana Andrijević-Derk, Zoran Vatavuk, Goran Benčić, Katia Novak-Lauš and Zdravko Mandić \\ University Department of Ophthalmology, Sestre milosrdnice University Hospital, Zagreb, Croatia
}

\begin{abstract}
SUMMARY - The aim of the study was to assess short-term efficacy of intravitreal bevacizumab in a series of patients with neovascular glaucoma. Eleven patients with neovascular glaucoma and symptomatic elevation of intraocular pressure were treated with $1.25 \mathrm{mg} / 0.1 \mathrm{~mL}$ of bevacizumab. In three patients, intravitreal bevacizumab was administered preoperatively, one day before pars plana vitrectomy. Additional therapy was only performed if topical medication failed to result in satisfactory control of intraocular pressure. Patients were followed-up for a minimum of 8 weeks. In all study patients, intravitreal application of bevacizumab resulted in marked regression of iris neovascularization within the first three postoperative days. Appropriate control of intraocular pressure was achieved in seven patients, whereas four patients required additional therapy for intraocular pressure regulation. No side effects of intravitreal bevacizumab were recorded. Thus, intravitreal bevacizumab seems to be a potent adjunct in the management of neovascular glaucoma. Additional studies of bevacizumab long-term safety and efficacy are warranted.
\end{abstract}

Key words: Glaucoma, neovascular - therapy; Neovascularization - pathology; Neovascularization - drug therapy

\section{Introduction}

The treatment of neovascular glaucoma has been perceived as one of the most challenging problems in ophthalmology. Some common causes of this serious secondary glaucoma are occlusive retinal vascular diseases such as central retinal vein occlusion (CRVO), central retinal artery occlusion (CRAO), diabetic proliferative retinopathy, inflammatory diseases and intraocular tumors ${ }^{1}$. Clinical symptoms and signs are also well known and include redness, discomfort and usually painful sensation in the eyes, iris and/or angle neovascularization with the formation of peripheral anterior synechiae (PAS), which may be absent in the late stage of the disease. The main problem in the treatment of this glaucoma is control of intraocular pressure (IOP) and prevention of new neovascularization and PAS that lead to angle closure and IOP increase ${ }^{2}$. The main trigger for

Correspondence to: Biljana Andrijević-Derk, MD, University Department of Ophthalmology, Sestre milosrdnice University Hospital, Vinogradska c. 29, HR-10000 Zagreb, Croatia

E-mail: biljana.andrijevic@zg.t-com.hr

Received January 25, 2008, accepted in revised form August 27, 2008 neovascularization is retinal ischemia. In such conditions, many vascular endothelial growth factors (VEGF) are released to exert their proangiogenic activity ${ }^{3}$.

A number of conservative and surgical modalities have been used in the management of neovascular glaucoma, however, none of them alone being efficient enough. Topical antiglaucoma medication ( $\beta$-adrenergic blockers, $\alpha$-adrenergic agonists, carbonic anhydrase inhibitors, prostaglandins) is used in the treatment of other types of glaucoma, but neovascular glaucoma is usually refractory to medical therapy. There are some procedures (like panretinal photocoagulation, diode laser cyclophotocoagulation) and surgical approaches (like filtering surgery with/without mitomycin and implantation of drainage implants) for this type of glaucoma, but the choice of treatment modality depends on the etiology and stage of neovascular glaucoma.

The aim of the neovascular glaucoma therapy is treatment of the basic cause of the disease, i.e. ischemia, and it is usually achieved by laser if the clarity of optical medium allows it. Laser photocoagulation destroys ischemic retinal areas and thus also decreases the concentration of proangiogenic factors (VEGF) by about 75 
percent, the latter being responsible for neovascularization of the retina, iris and angle ${ }^{2,3}$. If laser procedure is hampered by poor medium clarity, then other treatment modalities have to be tried, including transconjunctival cyclophotocoagulation, diode laser photocoagulation of peripheral retina, and filtering operations with mitomycin $\mathrm{C}$ or placement of drainage implants.

Concerning therapeutic modalities for neovascular glaucoma, bevacizumab has recently been increasingly investigated as a promising treatment option. There are many studies discussing the role and efficacy of bevacizumab in the management of neovascular glaucoma ${ }^{4}$. Bevacizumab (Avastin, F. Hoffmann - La Roche, Basel, Switzerland) as a monoclonal human antibody of all VEGF isoforms has been approved by the US Food and Drug Administration (FDA) only for metastatic colon cancer. It is in "off-label" use for the wet type of agerelated macular degeneration ${ }^{5,6}$, macular edema (in CRVO and diabetic macular edema) ${ }^{7-9}$, and for neovascular glaucoma of various etiology.

The aim of this study was to assess short term efficacy of intravitreal bevacizumab in a series of patients with neovascular glaucoma.

\section{Patients and Methods}

The study included 11 patients with symptomatic IOP elevation due to neovascular glaucoma. Proliferative retinopathy was the most common etiology of neovascular glaucoma. Other causes are shown in Table 1.

\section{Table 1. Etiology of neovascular glaucoma}

\begin{tabular}{|c|c|c|c|}
\hline Etiology & $\begin{array}{l}\text { Number } \\
\text { of patients }\end{array}$ & $\begin{array}{l}\text { Age } \\
\text { (yrs) }\end{array}$ & $\begin{array}{l}\text { Sex } \\
(\mathrm{f} / \mathrm{m})\end{array}$ \\
\hline \multirow{6}{*}{ PRD } & \multirow{6}{*}{6} & Pt. 148 & $\mathrm{~F}$ \\
\hline & & Pt. 263 & M \\
\hline & & Pt. 368 & M \\
\hline & & Pt. $4 \quad 71$ & $\mathrm{~F}$ \\
\hline & & Pt. 558 & M \\
\hline & & Pt. 659 & M \\
\hline \multirow{4}{*}{ CRVO } & \multirow{4}{*}{4} & Pt. 156 & M \\
\hline & & Pt. 264 & $\mathrm{~F}$ \\
\hline & & Pt. 366 & M \\
\hline & & Pt. 474 & $\mathrm{~F}$ \\
\hline CRAO & 1 & Pt. 169 & $\mathrm{M}$ \\
\hline Total & 11 & & $4 / 7$ \\
\hline
\end{tabular}

$\mathrm{PDR}=$ proliferative diabetic retinopathy $\mathrm{CRVO}=$ central retinal vein occlusion; $\mathrm{CRAO}=$ central retinal artery occlusion
Comprehensive eye examination at baseline and after treatment included best corrected visual acuity, applanation tonometry, biomicroscopy, gonioscopy, fundus examination and iris fluorescein angiography.

All patients were administered $1.25 \mathrm{mg} / 0.1 \mathrm{~mL}$ of bevacizumab intravitreally in sterile conditions in operating room. Preoperative cleaning of the eye was performed with $10 \%$ iodide solution, diluted with saline. Then, the site of application was determined at 3.5-4 $\mathrm{mm}$ from corneal limbus. Intravitreal application was performed with insulin needle, at right angle to the eye globe. After the application, antibiotic ointment was applied and the eye was covered.

Three patients received bevacizumab preoperatively, 3 days before pars plana vitrectomy. Additional treatment was only used if topical antiglaucoma medication failed to produce satisfactory IOP control. The patients were followed-up for at least 8 weeks.

\section{Results}

At baseline, visual acuity ranged from finger counting to light perception in all visual field quadrants. All patients had marked iris neovascularization verified on biomicroscopy (Fig. 1). The mean preoperative and postoperative IOP was $40 \pm 6 \mathrm{~mm} \mathrm{Hg}$ and $20 \pm 5 \mathrm{~mm} \mathrm{Hg}$, respectively. Gonioscopy revealed angle neovascularization in all 11 patients; however, 5/11 patients had narrower but open angle (grade II-III, sec. Schei) with partial iridotrabecular synechiae in less than a quarter $(<1 /$ 4 ) of angle circumference. Visual acuity, IOP before and after the application of bevacizumab and gonioscopy findings are shown in Table 2.

Preoperative iris fluorescein angiography demonstrat-

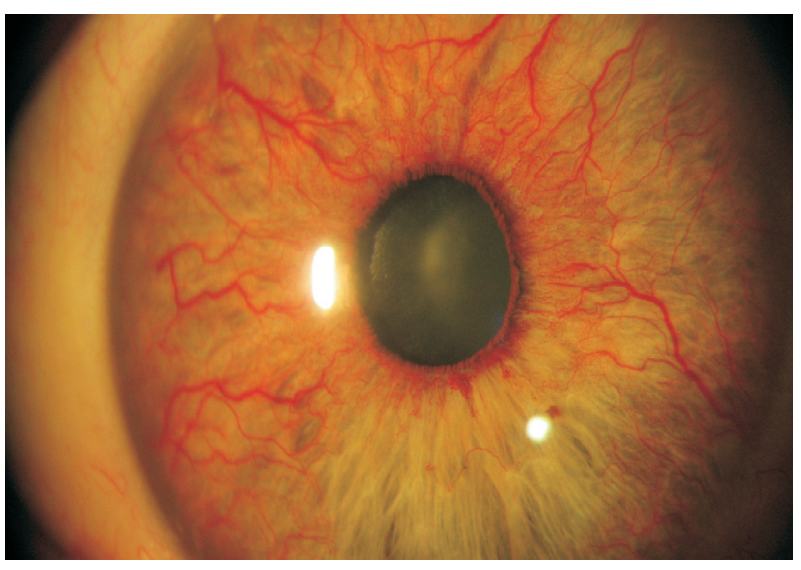

Fig. 1. Iris neovascularization on preoperative biomicroscopy. 

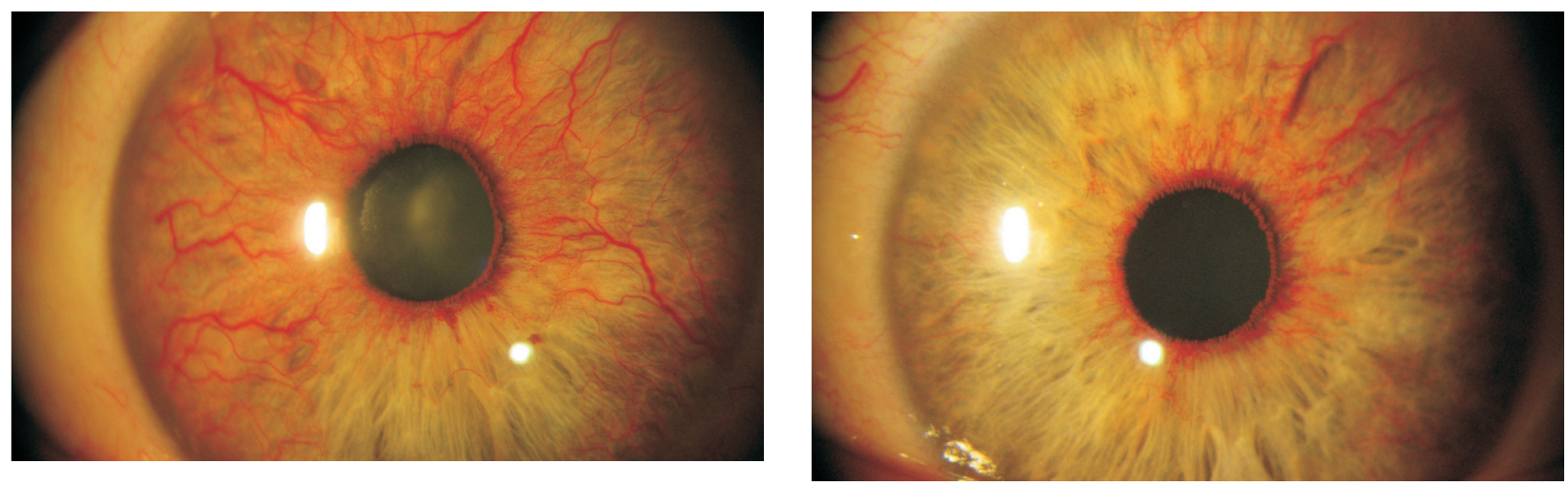

Fig. 2. Biomicroscopy of neovascularization before and after bevacizumab application: left - before bevacizumab application; right - after bevacizumab application.

ed massive leakage from the neovascularization. On postoperative day 3 , marked regression was recorded on biomicroscopy (Fig. 2) and verified on iris fluorescein angiography (Fig. 3).

In seven patients, good IOP control was achieved with topical antiglaucoma medication alone. Only 4/11 patients required additional treatment for IOP reduction, which included filtering surgery (2 patients), implantation of drainage valvule (1 patient) and cyclocryopexia (1 patient). No side effects or complications associated with the administration of bevacizumab were observed.

\section{Discussion}

Bevacizumab has recently come in the focus of interest of researchers. Study reports discuss its role in
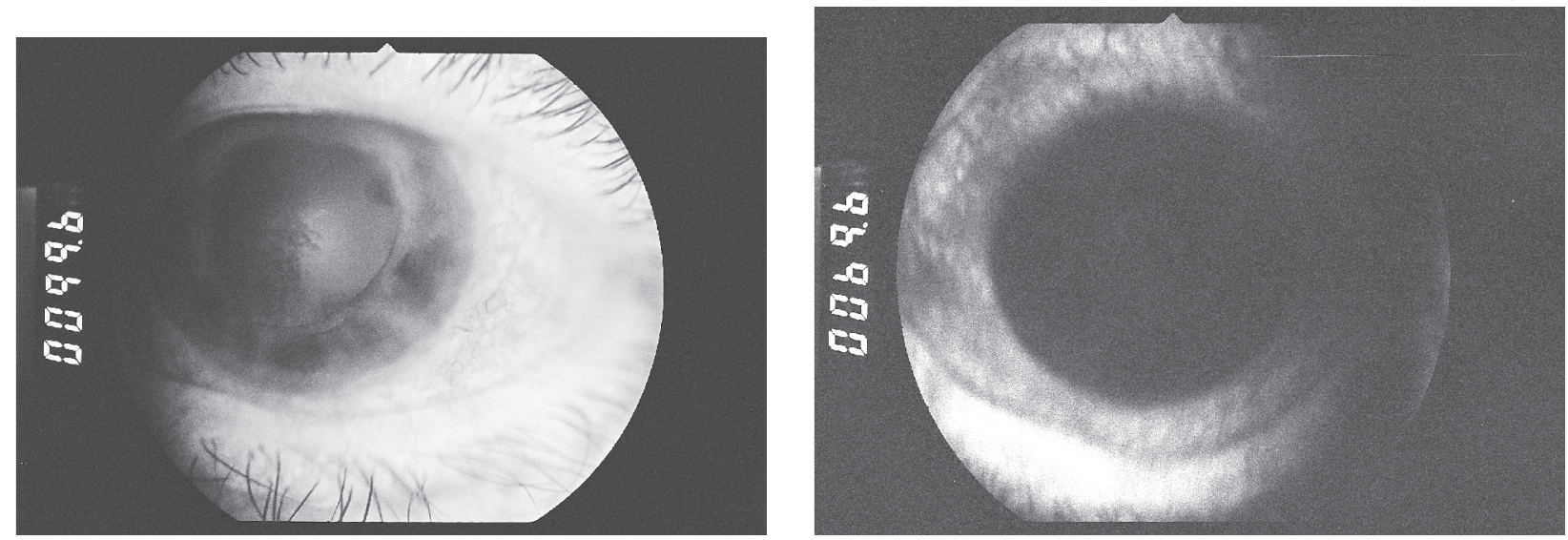

Fig. 3. Iris fluorescein angiography before and after bevacizumab application: left - before bevacizumab application; right - after bevacizumab application. 
Table 2. Visual acuity, intraocular pressure (before and after bevacizumab), and gonioscopy findings

\begin{tabular}{|c|c|c|c|c|c|}
\hline & & $\mathrm{VA}$ & $\begin{array}{r}\text { IOP } \\
\text { bef }\end{array}$ & $\begin{array}{l}\mathrm{nHg} \\
\text { after }\end{array}$ & $\begin{array}{l}\text { Gonioscopy } \\
\text { (sec. Schei) }\end{array}$ \\
\hline & Pt. 1 & $\mathrm{FG}$ & 44 & 22 & $\mathrm{NV}+$, open angle I/II \\
\hline & Pt. 2 & $\mathrm{FC}$ & 33 & 18 & $\mathrm{NV}+$, open angle I \\
\hline PDR 6 natients & Pt. 3 & $\mathrm{~L}+\mathrm{P}+$ & 46 & 20 & $\mathrm{NV}+$, narrow angle II/III \\
\hline Fo о о patients & Pt. 4 & $\mathrm{~L}+\mathrm{P}-$ & 48 & 24 & $\mathrm{NV}+$, narrow angle II/III \\
\hline & Pt. 5 & $\mathrm{FG}$ & 32 & 18 & $\mathrm{NV}+$, open angle I/II \\
\hline & Pt. 6 & $\mathrm{~L}+\mathrm{P}+$ & 46 & 22 & $\mathrm{NV}+$, narrow angle II/III \\
\hline & Pt. 1 & $\mathrm{FG}$ & 40 & 21 & $\mathrm{NV}+$, open angle I \\
\hline CRVO & Pt. 2 & $\mathrm{~L}+\mathrm{P}+$ & 42 & 20 & $\mathrm{NV}+$, narrow angle II/III \\
\hline 4 patients & Pt. 3 & FG & 38 & 20 & $\mathrm{NV}+$, open angleI/II \\
\hline & Pt. 4 & $\mathrm{FC}$ & 40 & 22 & $\mathrm{NV}+$, narrow angle II/III \\
\hline $\begin{array}{l}\text { CRAO } \\
1 \text { patient }\end{array}$ & No1 & & 40 & 18 & $\mathrm{NV}+$, open angle I/II \\
\hline
\end{tabular}

$\mathrm{PDR}=$ proliferative diabetic retinopathy; $\mathrm{CRVO}=$ central retinal vein occlusion; $\mathrm{CRAO}=$ central retinal artery occlusion; $\mathrm{VA}=$ visual acuity; $\mathrm{IOP}=$ intraocular pressure; $\mathrm{FC}=$ finger counting; $\mathrm{L}+\mathrm{P}+=$ light perception, projection in all quadrants

neovascular glaucoma. Our study suffered from limitations of the short follow up period (only 8 weeks) and a small number of study patients $(n=11)$. The study should be extended to a greater series of patients to allow for valid conclusions to make. However, it should be noted that a satisfactory IOP control was achieved in seven patients and that no side effects or complications were recorded during the study and follow up period, which is consistent with literature data ${ }^{1,2,4}$.

Other indications for the use of bevacizumab have been introduced and researched by authors like Jonas $e t$ $a l .^{10}$, who suggest its usage before filtering surgery in order to prevent excessive bleeding. Following this experience, less surgical complications and bleeding were noticed in patients that received bevacizumab 3 days before pars plana vitrectomy. Some authors have gone further and broadened the indications for bevacizumab, like Shah et al. ${ }^{11}$, who used it for retinopathy of prematurity in order to reduce anterior segment ischemia after aggressive laser treatment. They bravely broadened the indications for bevacizumab, but more studies have to be done on the issue to get satisfactory answers on the role and reasonable indications for the use of bevacizumab.

\section{Conclusion}

The usage of bevacizumab in neovascular glaucoma seems to have an adjunctive role to other treatment modalities. Very soon after its application, iris neovascularization markedly regressed, as verified by biomicroscopy and reduction of leakage on iris fluorescein angiography. IOP was sufficiently controlled without medication in seven of 11 patients, whereas only four patients required additional treatments.

Intravitreal application of bevacizumab seems to be safe and free from side effects and ocular complications. Recently, the indications for bevacizumab usage have been extended to the management of retinopathy of prematurity, prevention of bleb failure and also before glaucoma surgery to reduce excessive bleeding. Many questions on bevacizumab pharmacokinetics, toxicity profile and way of application have yet to be answered through multicenter prospective studies and longer follow up.

\section{References}

1. AL-ASWAD L. Another role for Avastin in neovascular glaucoma. Rev Ophthalmol 2006;13:06.

2. AL-ASWAD L. Anti-VEGF drugs and neovascular glaucoma. Rev Ophthalmol 2007;14:03.

3. AIELLO LP, AVERY RL, et al. Vascular endothelial growth factor in ocular fluid of patients with diabetic retinopathy and other retinal disorders. N Engl J Med 1994;331:1480-7.

4. ILJEV ME, DOMIG D, WOLF-SCHNURRBURSCH U, WOLF S, SARRA GM. Intravitreal bevacizumab (Avastin) in the treatment of neovascular glaucoma. Am J Ophthalmol 2006; 
142:1054-6.

5. GIANSANTI F, VIRGILI G, BINI A, RAPIZZI E, GIACOMELLI G, DONATI MC, et al. Intravitreal bevacizumab therapy for choroidal neovascularization secondary to agerelated macular degeneration: 6-month results of an open-label uncontrolled clinical study. Eur J Ophthalmol 2007;17:230-7.

6. AVERY RL, PIERAMICI D, RABENA M, et al. Intravitreal bevacizumab (Avastin ${ }^{\circledR}$ ) for neovascular age-related macular degeneration. Ophthalmology 2006;113:363-72.

7. AREVALO JF, FROMOW-GUERRA J, QUIROZ-MERCADO H, SANCHEZ JG, WU L, MAIA M, et al.; Pan-American Collaborative Retina Study Group. Primary intravitreal bevacizumab (Avastin) for diabetic macular edema: results from the
Pan-American Collaborative Retina Study Group at 6-month follow-up. Ophthalmology 2007;114:743-50.

8. AVERY R, PEARLMAN J, PIERAMICI DJ, RABENA MD, CASTELLARIN AA, NASIR MA, et al. Intravitreal bevacizumab (Avastin) in the treatment of proliferative diabetic retinopathy. Ophthalmology 2006;113:1695-705.

9. VATAVUK Z, BENČIĆ G, MANDIĆ Z. Intravitreal bevacizumab for neovascular glaucoma following central retinal artery occlusion. Eur J Ophthalmol 2007;17:1-6.

10. JONAS JB, SPANDAU UH, SCHLICHTENBREDE F. Intravitreal bevacizumab for filtering surgery. Ophthalmic Res 2007;39:121-2.

11. SHAH PK, NARENDRAN V, TAWANSY KA, RAGHURAM A, NARENDRAN K. Intravitreal bevacizumab (Avastin) for post laser anterior segment ischemia in aggressive posterior retinopathy of prematurity. Indian J Ophthalmol 2007;55:75-6.

Sažetak

\section{INTRAVITREALNA PRIMJENA BEVACIZUMABA U LIJEČENJU NEOVASKULARNOG GLAUKOMA}

\section{B. Andrijević-Derk, Z. Vatavuk, G. Benčić, K. Novak-Lauš i Z. Mandic}

Gilj ove studije bio je procijeniti kratkotrajni učinak intravitrealne primjene bevacizumaba u skupini bolesnika s neovaskularnim glaukomom. U studiju je bilo uključeno jedanaestoro bolesnika s neovaskularnim glaukomom i simptomatskim povišenjem očnog tlaka. Kod svih bolesnika primijenjen je bevacizumab u dozi od 1,25/0,1 mL intravitrealno. Kod troje bolesnika je bevacizumab primijenjen jedan dan prije pars plana vitrektomije. Dodatna antiglaukomska terapija primijenjena je samo kod onih bolesnika u kojih očni tlak nije bio dobro kontroliran lokalnom antiglaukomskom terapijom. Najkraće razdoblje praćenja bolesnika bilo je 8 tjedana. Intravitrealna primjena bevacizumaba dovela je kod svih bolesnika do značajne regresije neovaskularizacije šarenice, što je trećega dana od primjene bevacizumaba potvrđeno biomikroskopski te fluoresceinskom angiografijom. U sedmoro bolesnika je očni tlak bio dobro kontroliran samo lokalnom antiglaukomskom terapijom. Kod četvoro bolesnika bilo je potrebno daljnje kirurško antiglaukomsko liječenje. Nisu zabilježene nuspojave kao niti komplikacije za vrijeme ili poslije intravitrealne injekcije bevacizumaba. Zaključuje se kako se intravitrealna primjena bevacizumaba čini dobrom dodatnom metodom u kombinaciji s ostalim terapijskim modalitetima liječenja neovaskularnog glaukoma. Dodatne studije kojima se ispituje dugotrajniji učinak i sigurnost intravitrealne primjene bevacizumaba su u tijeku i one će doprinijeti boljem razumijevanju farmakokinetike, toksičnosti i putova primjene bevacizumaba u liječenju neovaskularnog glaukoma.

Ključne riječi: Glaukom, neovaskularni - terapija; Neovaskularizacija-patologija; Neovaskularizacija-terapija lijekovima 
30. 11. $08,18: 31$ 